\title{
A POSSIBLE ROLE OF ALPHA ADRENERGIC RECEPTORS IN SALIVATION INDUCED BY ISOPROTERENOL IN MICE.
}

\author{
Hideyo OHSHIKA, Junichiro LNDO, HarUo TAKEMURA \\ and Mamoru TANAKA \\ Detpatmont of Pharmacolegry, Sapporo Medical Collese, \\ Sapporo 060, Japan \\ Accepled May 4, 1978
}

It has been reported that salivation can be induced by sympathetic stimulation in mammals (1). The results of comparative studies of the salivary response to sympathomimetic amines in mice indicated that the salivation induced by isoproterenol occurred less remarkably than that by alpha adrenergic anines, adrenaline and noradrenaline. On the basis of in vitro experiments using slices of the salivary gland of rats, it is evident that the secretion of amylase from the parotid gland was evoked maiıly by stimulation of the beta adrenergic receptors $(2,3)$, and potassium release from the submaxillary gland was mainly the result of alpha adrenergic stimulation $(4,5)$, with beta adrenergic stimulation playing only a slight role. It has been suggested that a large dose of isoproterenol, especially after beta adrenergic receptor blockade, caused an additional stimulation of alpha adrenergic receptors in some smooth muscles (6). The present work was an attempt to determine whether a large dese of isoproterenol would produce additional alpha action of the sallivation in mice, and to determine the presence or absence of influences of beta adrenergic receptor blockade on the salivary effect of isoproterenol in mice.

Male dd strain mice weighing 25 to $30 \mathrm{~g}$ were used in all of the experiments. Animals were positioned under an incandescent lamp to maintain rectal temperature at $38 \mathrm{C}$. To measure the amount of salivary secretion, wrethane-anesthetized mice were placed in a prone position on filter papers, and the spots of saliva secreted on the paper were encircled with a pencil at intervals of five min after intraperitoneal injection of a sialogogue as described by Richter (7). The amount of saliva secreted during $30 \mathrm{~min}$ was measured as the total spot area per mouse. dl-Isoproterenol was given i.p. and adrenergic blocking agents were given i.v. 10 min before administration of the sialogogue. The saliva of guinea pig was used to ascertain the linear relationship betwcen the volume of saliva and salivary spot area produced by a corresponding volume. The relation of volume of saliva to the spot area was well correlated as shown in a linear relationship plotted between the two within a volume range of 0.1 to $2.0 \mathrm{ml}$.

Isoproterenol-induced salivation in mice was a dose-dependent response in a dose range of 0.2 to $2.0 \mathrm{mg} / \mathrm{kg}$ body weight. When isoproterenol was given at a dose of $2.0 \mathrm{mg} / \mathrm{kg}$, however, the dose-response curve in salivation formed a plateau up to $20 \mathrm{mg} / \mathrm{kg}$. To study further effects of isoproterenol on salivation, $10 \mathrm{mg}$ as a small dose and $100 \mathrm{mg}$ as a massive dose were used througlout the succeeding experiments. In the mouse, isoproterenol produced less severe toxic effects even in massive doses of $100 \mathrm{mg} / \mathrm{kg}$. The salivation 
induced by isoproterenol in the observed period was $575 ! 86 \mathrm{~mm}^{2}$ with $10 \mathrm{mg}$ and $978 \pm 71 \mathrm{~mm}^{2}$ with a $100 \mathrm{mg}$ dose.

As shown in Fig. 1, salivation induced by a small dose of isoproterenol decreased after pretreatment of beta adrenergic blocking agents in a dose of $10 \mathrm{mg} / \mathrm{kg}$, by $20 \%$ after sotalol and by $80 \%$ after propranolol. The salivation was completely abolished after oxprenolol. The response to the large dose of isoproterenol tended to increase with pretreatment of both propranolol and sotalol in doses of $10 \mathrm{mg} / \mathrm{kg}$. The basal salivation was not modified by those beta adrenergic blocking agents.

Alter pretreatment with alpha adrenergic blocking agents, isoproterenol-induced salivation was investigated in mice. As shown in Fig. 1, the salivary response to the large dose of the sialogogue was inhibited remarkably by alpha adrenergic blockers, namely 54 , 3.3 and $29 \%$ reduction by phenoxybenzamine, phentolamine and azapetine, respectively. Howcver, the anticholinergic agent, atropine $(1 \mathrm{mg} / \mathrm{kg})$, produced no change in the isoproterenol $(100 \mathrm{mg} / \mathrm{kg}$ )-induced salivation. It was of interest that labetalol, a new synthetic substance which was found to have a blocking effect on both alpha- and beta-adrenergic receptors in various organs (8), produced no inhibitory effect on the salivary action after a large dose of isoproterenol.

Regarding the enhanced response to the large dose of isoproterenol, another mechanism may be involved. Schramu (9) and Jonason (10) ascertained that a large amount of catecholamines was contained endogenously in the tissues of salivary glands of mice, and suggested that such catecholamines could be released from their storage sites by sympathetic nerve impulses and may produce excitation of the alpha adrenergic receptors.

To determine the role of endogenous catecholamines in salivation, reserpine $(5 \mathrm{mg} / \mathrm{kg}$ ) was administered twenty hours prior to sialogogue administration. Pretreatment with reserpine resulted in an increase of the response to isoproterenol as shown in Fig. 2 . This

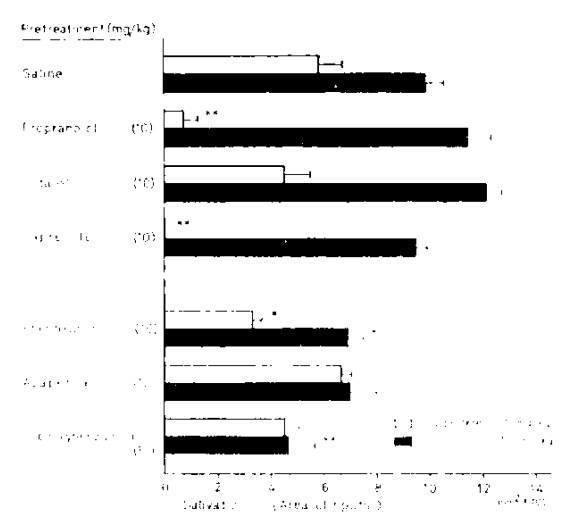

Fici. 1. Effects of alpha and beta adrenergic blocking agents on the salivation response $10 \mathrm{dl}$-isoproterenol in mice. Vertical bars: Means S.E.. : : P.0.05, ㅈ: P.0.01, significantly different from the salinetreated group.

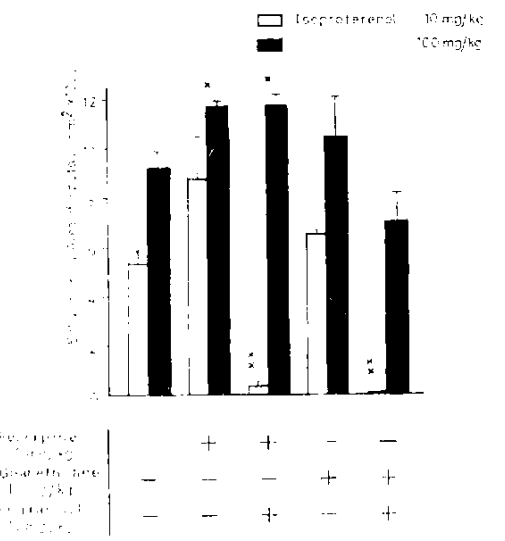

Fig. 2. Effect of pretreamont with rescrpine and guancthidine on the salivation response to dl-isoproterenol in mice. Vertical bars: Means-i-S.E. $\times: ~ P<0.05$, $\times \times: P<0.01$, significantly different from the saline-pretreated group. 
result may be explained as a sensitization of alpha adrenergic receptors in salivary glands as well as in other organs. Martinez and Quissell (11) reported that, in experiments using submaxillary gland slice of rats, the extent of potassium release by noradrenaline was higher in slices from reserpine-treated animals than that from non-treated animals, suggesting an increased volume of saliva in the reserpine-treated animals due to the stimulation of alpha adrenergic receptors. In the present experiments using reserpinized mice, propranolol suppressed the effect of the small dose (10 nng/ $/ \mathrm{kg}$ ) of isoproterenol, however, had no effect when a large dose $(100 \mathrm{mg} / \mathrm{kg})$ of the sialogogue was given. On the other hand, although the effect of isoproterenol remained unaltered with guanethidine pretreatment, pretreatment with guanethidine combined with propranolol significantly reduced the salivation response to the small dose of isoproterenol.

The mechanism of excitation of the alpha adrenergic receptors with a large dose of isoproterenol remains obscure. Both alpha and beta adrenergic receptors may be excited sinultaneously with a large dose of this compound. However, to produce the alpha adrenergic effect, a sufficient concentration at the site of action would have to be maintained. The salivary effect of the alpha agonist is stronger than that of the beta agonist in comparison with molar dose, and therefore a remarkable salivary response is expected with a large dose of isoproterenol. On the other hand, the small dose of isoproterenol may be insufficient for the alpha adrenergic offect, even in the presence of a beta adrenergic blocking agent. In the case of a large dose of isoproterenol, beta adrenergic blocking agents may eliminate the isoproterenol-induced suppression of potassium release from the salivary glands (5). Thus we concluded that isoproterenol may produce salivation in mice by excitation of beta adrenergic and partially alpha adrenergic receptors in the salivary glands.

\section{REFERENCES}

1) EMmpin, N.: Pharmacology of salivary glands. Handbook of Physiology, Alimentary Canal, Vol. 2, p. 665-678, Edited by Code, C.F., Am. Physiol. Soc., Washington D.C. (1967); 2) BatzRI, S. AND St:INGER, Z.: Enzyme secretion mediated by the epinephrine 6 -receptor in rat parotid slices. Factors governing efficiency of the process. J. hiol. Chem. 248, 356-360 (1973); 3) LfFIfi, B.A., Pltwey, J.W. JR. AND Shfrmav, J.M.: a-Adrenergic, ;-adrenergic and cholinergic mechanisms for amylase secretion by rat parotid gland in vitro. J. Physiol. 260, 351-370(1976); 4) BATZR1, S., Selinger, Z., Schramu, M, and Rolinovitcil, M.R.: Potassium release mediated by the epinephrine $\alpha$-receptor in rat parotid slices. Properties and relation to enzyme secretion, $J$. biol. Chem. 248, 361-368 (1973); 5) Maritnl7, J.R., Quisslal, D.O. and Gilfs, M.: Potassium relcase from the rat submaxillary gland in vitro. I. Induction by catecholamines. J. Pharmacol. cxp. Ther. 198, 385-394 (1976); 6 INNES, I.R. AND NICKERSON, M.: Norepinephrine, epinephrine, and the sympathomimetic amines. The Pharnacological Basis of Therapentics. 5 hh Fd., Edited by Goommiv, L..S. AND Gilmav, A., p. 477-513, MacMillan, New York (1975); 7) Richnt R, W.: Estimation of anticholinergic drug effects in mice by antagonism against pilocarpine-induced salivation. Acta phamacol. toxicol. 24, $243-254$ (1966); 8) BRITTAIN, R.T. AND LEvY, G.P.: A revicw of the animal pharmacology of labetalol, a combined $a$ - and $\beta$-adronoceptor-blocking drug. Brit. J. clin. Phamacol. 344) Suppl. 681-694 (1976); 91 Schram, M.: Amylase secretion in rat parotid slices by apparent activation of endogenous catecholamine. Biochim. Biophys. Acta $165,546549(1968) ; 10)$ IoNASON, I.: Effects of reserpine on the noradrenaline content of atrophied rat salivary glands. Acta physiol. scand. 75, 73-77 (1969): 11) MARTINI.7. J.R. AND Quissell, D.O.: Potassium release from the rat subnaxillary gland in vitro. III. Effects of pretreatment with reserpine. J. Pharmacol. exp. Ther. 201, 206-217 (1977) 